\title{
Agriculture
} Ecosystems \& Environment

ELSEVIER

\section{Staphylinid beetles as bioindicators}

\author{
Jaroslav Bohac \\ Institute of Landscape Ecology, Academy of Sciences of the Czech Republic, Na sadkach 7, 37005 Ceske Budejovice, Czech Republic
}

\begin{abstract}
The family Staphylinidae is one of the largest beetle families and is distributed worldwide in almost all types of ecosystems. The morpho-ecological characteristics of staphylinid beetle adults and developmental stages are summarized, and features pertaining to their potential use as bioindicators are highlighted. Methods of study and practical examples are given for the application of staphylinids as bioindicators both in seminatural and cultural landscapes. The structure of staphylinid communities in biotopes with various management practices is described. Future refinements in identification and sampling methods should result in increased use of staphylinids as bioindicators, possibly in combination with studies of other insects competing for the same resources. (C)1999 Elsevier Science B.V. All rights reserved.
\end{abstract}

Keywords: Staphylinidae; Communities; Seminatural and rural areas; Management; Bioindicators

\section{Staphylinid beetles - general biology}

The family Staphylinidae is one of the largest families of beetles, with about 32,000 known species (Newton, 1990). The family is distributed worldwide and is found in practically all types of ecosystems. About half of the staphylinid species are found in litter, forming one of the most common and ecologically important insect components of the soil fauna. Knowledge of the broad habitat requirements of common staphylinid species and the fact that the family is distributed in practically all semi-natural and man-made habitats are two features that make staphylinids attractive as potential bioindicators. In spite of this, staphylinids are used less often in bioindicative studies compared with ground beetles, primarily because of the practical difficulties associated with staphylinid taxonomy. Nevertheless, the excellent keys for determination of staphylinids of central Europe by Lohse (1964) and Lohse et al. (1974) make it possible to identify practically all common species of staphy- linids in central Europe. This paper presents general information about the morphology and ecology of staphylinid adults and developmental stages, followed by data regarding the possible application of staphylinids as bioindicators and a description of the structure of beetle communities in selected biotopes. The data concerning staphylinids as bioindicators are based on studies made in three biogeographic zones: taiga (southern part), lowland forest and forest steppe. The literature cited focuses mainly on western, central and eastern Europe.

\subsection{Staphylinid beetles - morphological characteristics}

Staphylinid adults are usually easily distinguished from other beetles by their short truncate elytra, which leave more than half of the rather flexible abdomen exposed (Fig. 1). The body is ovoid to very elongate, with a yellowish to dark color; other colours (red, blue, yellow) are rare. Body shape, 

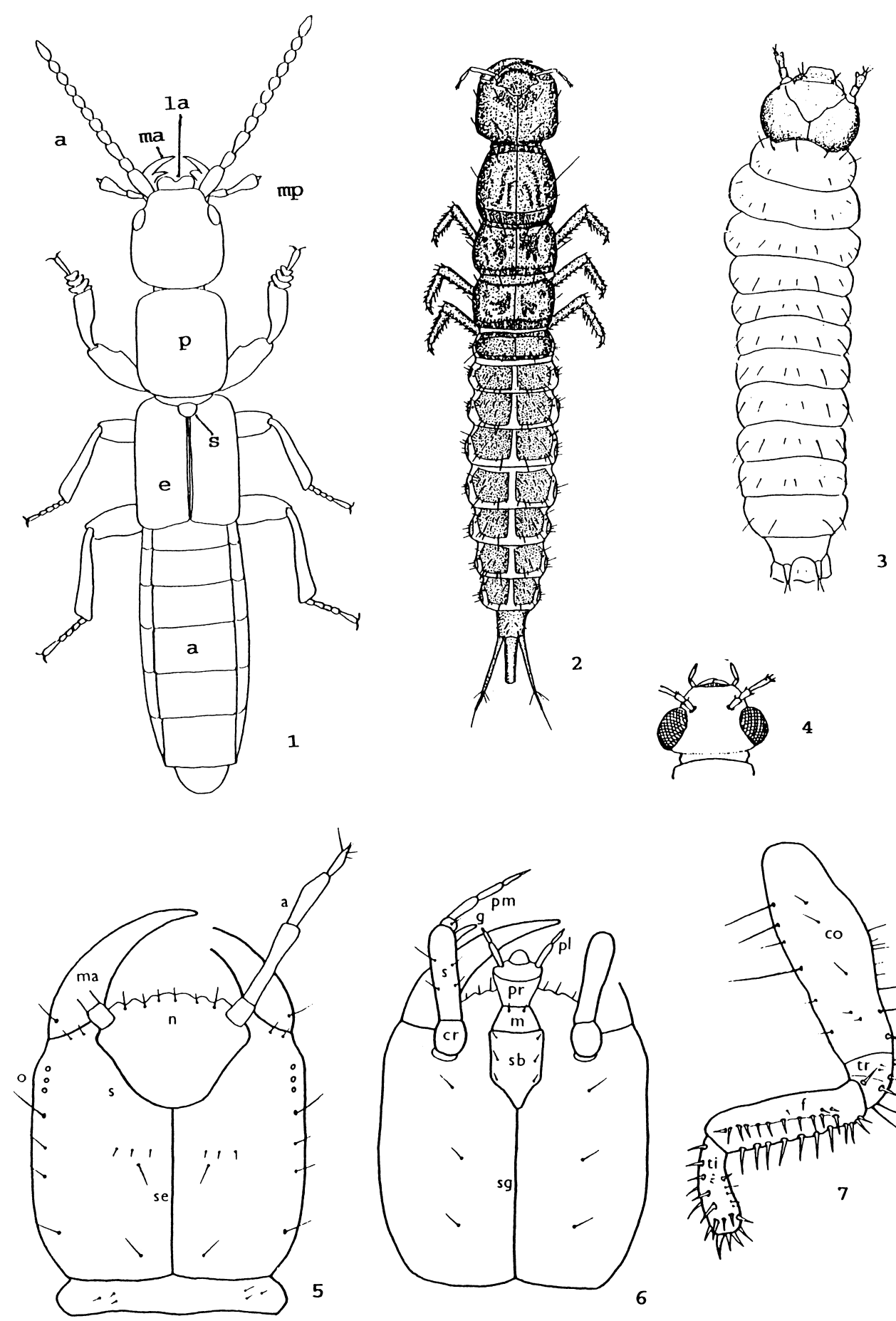

Figs. 1-7. 1. Lathrobium filiforme; a: antenna, la: labrum, ma: mandible, mp: maxillary palp, p; pronotum, s: scutellum, e: elytra, a: abdomen. 2. Ocypus nero semialatus, larva. 3. Platystethus nitens, larva. 4. Stenus comma, head. 5. Ocypus sp., head of larva, ventral view; pm: maxillary palp, g: galea, pl: labial palp, s: stipes, sb: submentum, m: mentum, pr: prementum, cr: cardo, sg: gular suture. 6. Ocypus sp., head of larva, dorsal view; ma: mandible, n: nasale, a: antenna, se: epicranial suture, sf: frontal suture. 7. Anterior leg of larva of the genus Staphylinus; cvo: coxa, tr: trochanter, ti: tibiotarsus, f: femur. 

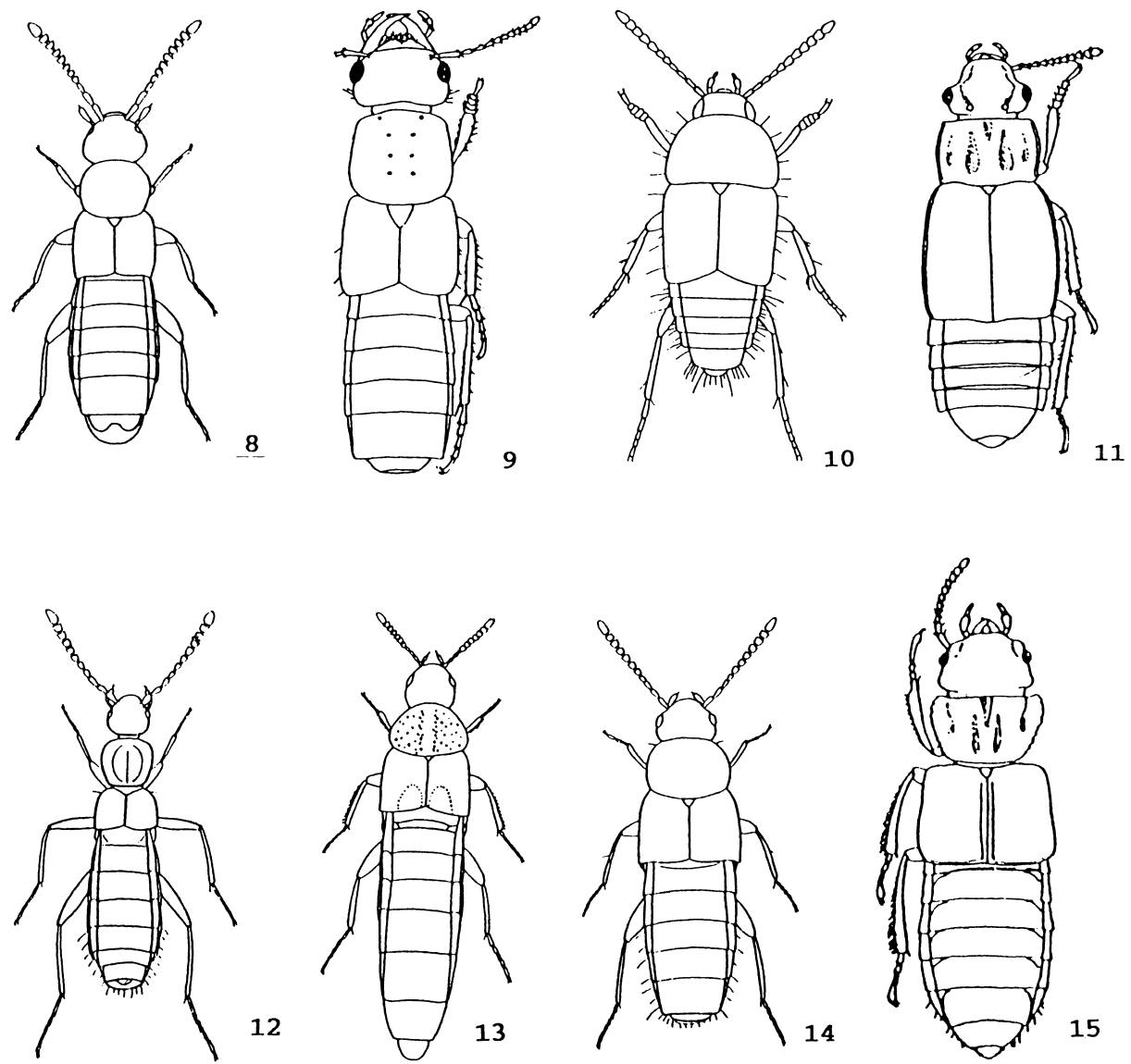

Figs. 8-15. Habitus of staphylinid species common in agricultural landscapes. 8. Oxytelus rugosus 9. Omalium rivulare 10. Philonthus cognatus 11. Tachyporus chrysomelinus 12. Amischa analis 13. Atheta fungi 14. Drusilla canaliculata 15. Aleochara bipustulata (from the book of Lohse (1964) and Lohse, Benick and Likovsky (1974)).

sensory adaptations, thoracic and basal abdominal structure and leg specializations can be explained in terms of locomotory specialization (Coiffait, 1972; Tikhomirova, 1973). Mouthpart adaptations reflect both the type of food and particular feeding method employed (Evans, 1964; Tikhomirova, 1973). The compound eyes vary from greatly reduced in size (terricolous species) to quite large (e.g. predaceous species of the genus Stenus) (Figs. 4 and 12). Details about staphylinid morphology are given by Blackwelder (1936), Smetana (1958), Lohse (1964), Coiffait (1972), Tikhomirova (1973), Naomi (1987) and Newton (1990). Larvae of staphylinid beetles have been poorly studied despite the fact that they are a relatively common component of the soil fauna. Most staphylinid larvae can be distinguished from most other beetle larvae by the presence of a pair of articulated appendages (urogomphi) at the apex of the ninth abdominal tergum (Fig. 2, 3). Staphylinids usually have three (rarely two) larval instars, with instars 2 and 3 more similar in structure than instar 1. Details about larval morphology are given by Paulian (1941), Pototskaya (1967), Topp (1978) and Bohac (1982). Staphylinid eggs are ovoid or oval (Hinton, 1981). The chorion is well developed and its surface pattern is characteristic for various taxonomic groups (Szujecki, 1966; Bohac, 1982). Small aeropyles are present on the egg surface. The eggs absorb water during their development and grow in size. Staphylinid pupae are of the pupa libera or pupa obtecta type (Bohac, 1982, 1988a). Pupa libera can actively move in the substrate. 


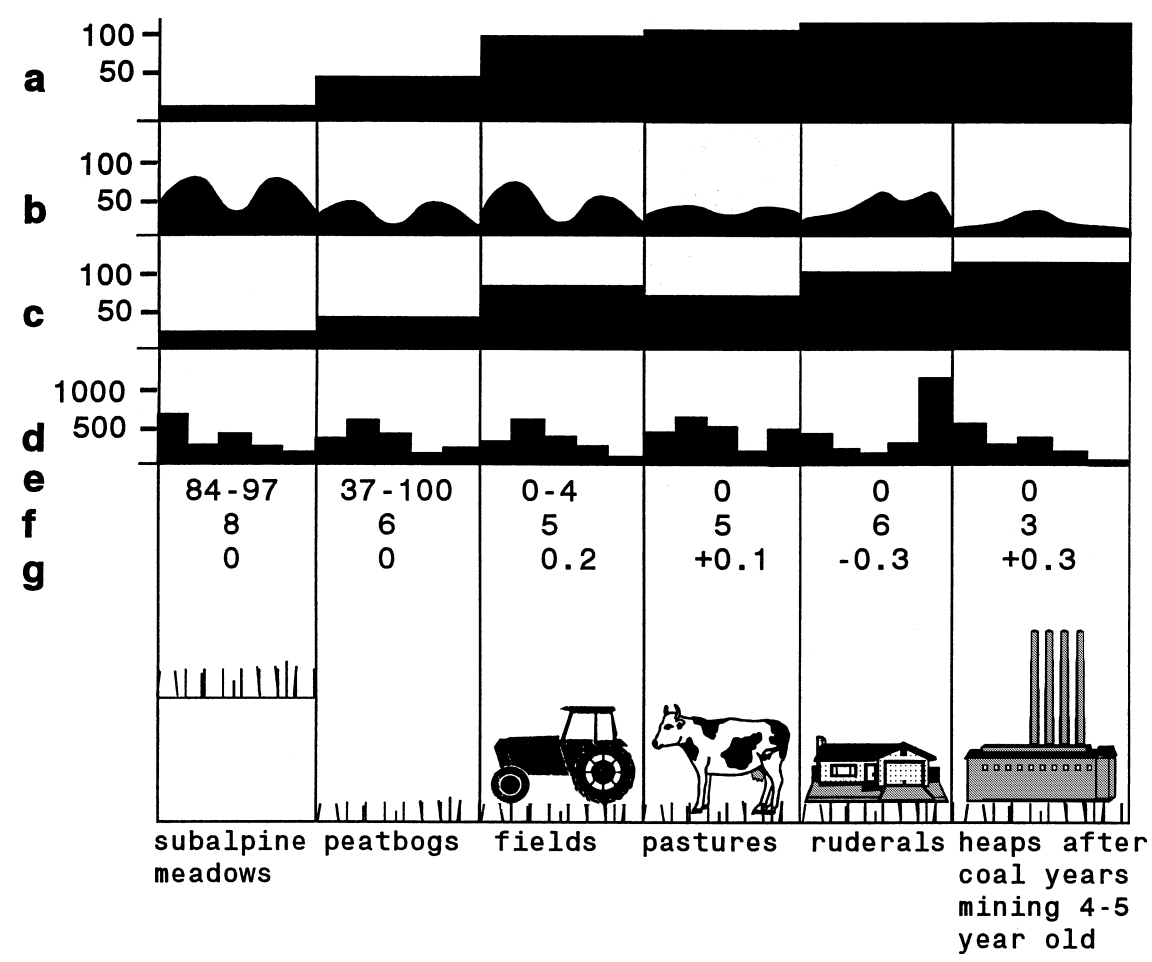

Fig. 16. The influence of man on communities of staphylinid beetles in non-forest landscapes: a: percentage of eurytopic species, b: seasonal dynamics (spec. $/ \mathrm{m}^{2}$ ), c: percentage of species with good migrating ability, d: distribution of individuals in relation to body size (spec.), e: index of community, f: number of life forms, g: sex ratio (female - male/N). Bars in panel D represent body size Groups I-V (from left to right) ranging from smallest to largest, respectively (see text) (after Bohac and Fuchs, 1991).

\subsection{Size groups of staphylinids}

The body length of adult staphylinids varies between $0.5-60 \mathrm{~mm}$ in the Holarctic region and most frequently ranges from 1 to $35 \mathrm{~mm}$. Species with such varied body size have different roles in ecosystems: often they are not in contact in the same biotope, with small species living mainly in the crevices of the soil and large species on the soil surface. Bohac and Ruzicka (1990) studied the size structure of staphylinid communities in different biotopes, including meadows, fields, oak forest, steppe forest, pond littorals and a transect through a valley of a brook comprising the brook shore, Aceri-Carpinetum type and oak forest and rocky steppe. The various species were assigned average size values based on published data (Lohse, 1964; Lohse et al., 1974), and the abundances of the species were plotted against their average body size in geometric scale with a quotient of 1.10 (Ruzicka, 1985). The abundances in relation to body size were centered around certain values rather than distributed uniformly. The positions of the abundance maxima were roughly the same in the different biotopes examined. The boundaries in the minima were established from the obtained diagrams, and refined on the basis of the authors' experience and measurements of the principal species collected from the communities. Five size groups were established, with Group I having a body length of up to $3.0 \mathrm{~mm}$; Group II, 3.1-4.5 mm; Group III, 4.6-7.0 mm; Group IV, 7.1-11.0 mm; and Group V, greater than $11.0 \mathrm{~mm}$. The frequency of size groups was found to differ in staphylinid communities in various biotopes (Bohac, 1988a; Bohac and Fuchs, 1991). The largest species (i.e., those in size Group V) prevail in ruderal biotopes in Central Europe (Fig. 16).

\subsection{Trophic habits of staphylinids}

The trophic groups of staphylinids serve as the basis for the hierarchic classification of their life forms (see 
Section 1.5), which is used in biomonitoring. The majority of staphylinids are known as non-specific predators, feeding on various soil arthropods such as nematodes, mites, Collembola, small insect imagos and larvae, etc. Staphylinid predators do not normally live under stones, but merely take shelter there, especially nocturnal species. Some species of Oxytelinae feed on various organic substances and thus their gut contents include quantities of organic matter. Species of the genus Bledius feed on algae. Species of the large genus Eushalerum, which feed on pollen, are trophic specialists. It is evident that many staphylinid species are mycetophagous (Newton, 1984; Bohac, 1988a). Some staphylinid beetles possess mycangia, which serve for transport of spores (Crowson, 1981). These mycangia are situated in cavities on the base of the mandibles and are very similar to those of other mycetophagous beetle species, e.g., Dendrophagus spp. (Cucujidae). Myrmecophilous and termitophilous staphylinids are specialized groups of predators eating ants and termites, respectively, or saprophages living on waste in or near ant or termite nests. The complicated relationships between staphylinids and social insects have been described by many authors (e.g., Wilson, 1971; Kistner, 1979). Some members of the genus Aleochara are known to be parasitoids of fly puparia (Fuldner, 1960; Frank, 1982; Ienistea and Alex, 1982, Frank, 1991).

\subsection{Diurnal activity and migrational possibilities of staphylinids}

Staphylinid beetles are active mainly during the day (Tikhomirova, 1973; Spicarova, 1982). However, the majority of staphylinids prefer dark or shaded microbiotopes and live in litter, under stones, etc., and their maximal activity is influenced by the intensity of lighting. Many staphylinids possess great migrational possibilities (Crowson, 1981); this ability differs among various species and groups. Many species are good flyers (e.g., species of the genera Oxytelus, Philonthus, Amischa, Atheta etc.), and many small species are carried by the wind for long distances (e.g., species of the genera Oxytelus, Amischa, Atheta). Some of these species, which are common in agricultural landcapes, can be found at high elevations on mountains. Some species can be transported by man and have been distributed in this way all over the world (e.g.,
Lithocharis nigriceps). In recent years the expansion of some species has occurred mainly from southeast Asia (e.g., Oxytelus migrator, Philonthus spinipes) (Bohac, 1988a). A high frequency of species with good migrating ability within a given staphylinid community indicates a strong influence of man on the biotope (Fig. 16).

\subsection{Life forms of staphylinids}

A hierarchic classification of life forms of staphylinid beetle adults was created by Krivoluckij and Bohac (1989) according to the method of Sharova (1981). On the basis of their trophic specialization, staphylinids were divided into five classes of life forms (Table 1). Zoophages appear to prevail among staphylinids in terms of trophic specialization. However, a significant proportion of staphylinid species are mycetophagous or saprophagous; phytophages and myrmecophils are present in lower numbers.

An investigation of the life form spectrum of staphylinid communities of 155 biotopes showed that the number of life forms can vary from 4 (sandlands) to 11 (cultivated meadows). The greatest variety of life forms was found in staphylinid communities living in natural or semi-natural ecosystems (forest, steppe, nonregulated riversides and brooksides, subalpine meadows, pond borders). For each of these ecosystems there is a characteristic predominance of individuals of certain life forms (Krivoluckij and Bohac, 1989). The spectrum of life forms of staphylinid adults is indicative of various ecological and anthropogenous parameters in ecosystems of open landscapes. Higher numbers of life forms are present in seminatural habitats that are less influenced by man (Fig. 16). The hierarchical classification of life forms of staphylinid larvae is similar to that of imagos (Table 1). A new class of parasitoids has been added to the system of life forms because of the existence of some ectoparasitic larvae of the genus Aleochara (Krivoluckij and Bohac, 1989).

\section{Staphylinids as bioindicators - methods of study}

Communities of staphylinids can be used as bioindicators of the environmental status and particularly of 
Table 1

Life form systems of staphylinid adults

\begin{tabular}{|c|c|}
\hline Class & Zoophages \\
\hline Sub-class & Epigeobios \\
\hline \multirow[t]{2}{*}{ Groups } & Epigeobionts, walking, large (Staphylinus type) \\
\hline & Epigeobionts, walking, small (Philonthus type) \\
\hline Sub-class & Stratobios \\
\hline \multirow[t]{5}{*}{ Groups } & living on soil surface and in decaying litter (Othius type) \\
\hline & living in decaying litter (Medon type) \\
\hline & living in decaying litter and under bark (Dinaraea type) \\
\hline & bothrobionts (Quedius type) \\
\hline & troglobionts (Domene cavicola type) \\
\hline Sub-class & Geobios \\
\hline \multirow[t]{2}{*}{ Groups } & Geobionts, running-grubbing (Phytosus type) \\
\hline & Geobionts, edaphic (Geostiba type) \\
\hline Sub-class & Psammocolimbets \\
\hline \multirow[t]{2}{*}{ Groups } & coastal (Stenus type) \\
\hline & living on light and sandy soils (Astenus type) \\
\hline Sub-class & Petrobios (Domene type) \\
\hline Sub-class & Torphobios (Gymnusa type) \\
\hline Class & Phytophages \\
\hline Group & $\begin{array}{l}\text { Dendrochortobionts (Eusphalerum type) } \\
\text { coastal (Bledius type) }\end{array}$ \\
\hline Class & Saprophages \\
\hline \multirow[t]{3}{*}{ Group } & living in decaying litter and soil (Omalium type) \\
\hline & Epigeobionts, small (Oxytelus type) \\
\hline & Troglophiles (Ochthephilus type) \\
\hline Class & Mycetophages (Gyrophaena type) \\
\hline Class & Myrmecophiles and Termitophiles \\
\hline \multirow{3}{*}{ Group } & Symphiles (Atemeles type) \\
\hline & Synechtres (Lamprinodes type) \\
\hline & Synoecentes (Thiasophila type) \\
\hline
\end{tabular}

human influence on ecosystems (Bohac, 1986, 1988a, 1988b, 1990; Bohac and Ruzicka, 1988; Ruzicka and Bohac, 1994). Staphylinids can be collected by pitfall trapping or by taking soil quadrat samples. The material should be collected during a one-year period and the same method should be used to compare various biotopes. The various indexes of species diversity can be calculated from the number of species and individuals in the sample (Ruzicka and Bohac, 1994). However, these indexes are based only on the species and specimen number and provide no information about the ecological characteristics of staphylinids. The author has proposed an index of staphylinid communities for the evaluation of the degree of human influence on ecosystems which is calculated on the basis of dividing beetles into ecological groups according to their relation to the naturalness of biotopes (Bohac, 1990). These groups are as follows: Group $\mathrm{R}$ includes species remaining from communities of past periods, e.g., species with arcto-alpine, boreomontane and boreo-alpine occurrence, inhabiting mainly mountains and peatbogs, or only occurring in remains of forests stands, which because of their high species diversity resemble recent climax forests; Group A encompasses species of both natural and managed forests; and Group E comprises eurytopic species that successfully occupy deforested sites and are also found in areas strongly affected by man. The index of staphylinid communities (IS) is a simple mathematical expression covering all three ecological groups $(\mathrm{R}, \mathrm{A}, \mathrm{E})$. It is defined as

$\mathrm{IS}=100-\left({ }_{i=1}^{n} \mathrm{E}+{ }_{i=1}^{n} \mathrm{~A}\right)$

where the first right-hand sum comprises the percentage abundance of individuals of eurytopic species (Group E), and the second the abundances of individuals of species of natural and managed forests (Group A). The value of this index ranges from 0 (only eury- 
Table 2

Parameters indicating the critical stage of staphylinid communities

Parameters

Frequency of ubiquitous specimens

Index of community

more than $90 \%$

Number of life forms

ess than 35

Frequency of large individuals (IV and V

size groups)

Frequency of individuals with summer activity

less than 4

Non flying species

Frequency of species with higher temperature requirements

Frequency of species with lower temperature requirements

more than $20 \%$

more than $40 \%$

absence

more than $70 \%$

more than $70 \%$

Value of sex ratio index

more than $10 \%$ from $1: 1$

topic species are present and the community is highly affected by man) to 100 (only species of group $\mathrm{R}$ are present and the community is virtually unaffected by man). Upon establishing the index values for different biotopes it is possible to characterize the degree of man's influence in the examined communities by a single figure, thus avoiding dubious comparisons with sparse controls. In addition, the relationship between the index values for a given biotope and the species abundances within the communities can be employed as an index of the sensitivity of various species to human-induced stress, and can also serve as a refinement of the classification (Bohac, 1990). Ecological analysis for evaluation of community structure was employed in a study of beetle communities in biotopes with different degrees of anthropogenic effects (Bohac and Fuchs, 1991). Various characteristics (frequency of ecological groups according to their relation to the naturalness of biotopes, frequency of species with summer and winter activity of imagos, proportion of winged species, various body size groups, thermoand hygropreference and geographical distribution) were used during this analysis (Fig. 16). Increased influence by man was found to bring about an increase in the frequency of eurytopic species, an increase in the frequency of species with summer activity of imagos, and a decrease in the proportion of species with winter activity of imagos. One peak in seasonal activity of staphylinids was found in biotopes with increased influence by man in contrast to two peaks in seasonal activity in semi-natural habitats. Furthermore, an increase was also seen in the proportions of winged species and individuals possessing a higher migrating ability, large body size (size Groups IV and V after Bohac and Ruzicka, 1990), species with higher temperature and lower moisture preferences, and species with an area of occurrence wider than Europe. A decrease in the number of life forms was accompanied by a decrease in the beetle community index. More extensive human activity was also shown to bring about an alteration of the sex ratio. The ecological analysis of staphylinid communities was used for evaluation not only of the author's data but also of data collected by other authors (Bohac, 1988a) and was able to identify the critical stage of communities, when staphylinid communities are unstable and their structure is changing year by year, mainly in response to various management practices (Table 2) (Bohac and Fuchs, 1991). Multivariate analysis has recently been applied to compare staphylinid communities of various biotopes (Bohac, 1994; Bohac and Fuchs, 1994a, 1994b, 1995; Bohac et al., 1995).

\section{Species diversity and ecological characteristics of staphylinids in managed and unmanaged areas}

Many ecological studies have been carried out on communities of staphylinids in various semi-natural and managed ecosystems (Bohac, 1988a). However, direct comparisons of beetle communities of various ecosystems are lacking. The author attempted to compare various communities using ecological analysis of staphylinid communities from published studies and his own data (Bohac, 1988a). The following section summarizes the data concerning staphylinid beetles in forests and wetlands (unmanaged ecosystems) and in fields (managed ecosystems). 
Table 3

The number of species and abundance (specimens $/ \mathrm{m}^{2}$ ) of staphylinid beetles in various natural, semi-natural and unmanaged ecosystems in studied biogeographic zones (1: southern taiga, 2: lowland forests, 3: foreststeppe)

\begin{tabular}{|c|c|c|c|c|c|}
\hline Ecosystem & Country & Zone & Source & $\begin{array}{l}\text { No. of } \\
\text { species }\end{array}$ & $\begin{array}{l}\text { No. of } \\
\text { individuals } / \mathrm{m}^{2}\end{array}$ \\
\hline Peat bog Sphagnum spp. & Russia & 1 & $\begin{array}{l}\text { Tikhomirova, 1982; Razumovskii et al., 1984; } \\
\text { Rybalov and Tikhomirova, } 1994\end{array}$ & $12-27$ & 86-198 \\
\hline Heathland & Russia & $\begin{array}{l}1 \\
1\end{array}$ & $\begin{array}{l}\text { Tikhomirova, 1982; Razumovskii et al. 1984; } \\
\text { Rybalov and Tikhomirova, } 1994\end{array}$ & $14-20$ & $78-110$ \\
\hline Pine forest & Russia & 1 & Tikhomirova, 1982; Rybalov and Tikhomirova, 1994 & $14-35$ & $75-118$ \\
\hline Birch forest & Russia & 1 & $\begin{array}{l}\text { Tikhomirova, 1982; Razumovskii et al., 1984; } \\
\text { Rybalov and Tikhomirova, } 1994\end{array}$ & $15-28$ & $62-124$ \\
\hline Spruce forest & Russia & 1 & $\begin{array}{l}\text { Tikhomirova, 1982; Razumovskii et al., 1984; } \\
\text { Rybalov and Tikhomirova, } 1994\end{array}$ & $12-21$ & $99-187$ \\
\hline Alder forest & Russia & 1 & $\begin{array}{l}\text { Tikhomirova, 1982; Razumovskii et al., 1984; } \\
\text { Rybalov and Tikhomirova, } 1994\end{array}$ & $27-35$ & $675-783$ \\
\hline Oak forest & Russia & 3 & Bohac et al., 1984 & 52 & $50-170$ \\
\hline Unmowed steppe & Russia & 3 & Bohac et al., 1984 & 45 & $190-220$ \\
\hline Mowed steppe & Russia & 3 & Bohac et al., 1984 & 46 & $40-60$ \\
\hline Hornbeam forest & Czechia & 2 & Bohac, 1986, 1988a, 1988b & 53 & $230-380$ \\
\hline Oak forest & Czechia & 2 & Bohac, 1986, 1988a, 1988b & 41 & $160-210$ \\
\hline Alder forest & Czechia & 2 & Bohac, 1986, 1988a, 1988b & 81 & $350-470$ \\
\hline Mixed pine-oak forest & Czechia & 2 & Bohac, 1986, 1988a, 1988b & 23 & $50-100$ \\
\hline Lime-maple forest on talus slope & Czechia & 2 & Bohac, 1986, 1988a, 1988b & $45-60$ & $5-80$ \\
\hline Littoral of stream & Czechia & 2 & Bohac, 1988a, 1988b & $40-54$ & $60-220$ \\
\hline Montane spruce forest & $\begin{array}{l}\text { Slovakia } \\
\text { Czechia }\end{array}$ & 2 & $\begin{array}{l}\text { Roubal, } 1930 \\
\text { Bohac, } 1988 \text { a }\end{array}$ & $36-52$ & $30-110$ \\
\hline Plantation forest of spruce & Czechia & 2 & Bohac, 1988a & $5-28$ & $5-68$ \\
\hline Peat bog & $\begin{array}{l}\text { Czechia } \\
\text { Germany }\end{array}$ & 2 & $\begin{array}{l}\text { Bohac, } 1988 \mathrm{a} \\
\text { Frisch, } 1995\end{array}$ & $31-113$ & $10-160$ \\
\hline
\end{tabular}

\subsection{Staphylinid communities in forest ecosystems}

Staphylinids are very common in semi-natural and managed forest ecosystems. The species diversity and ecological structure of communities differs in various types of forest (Table 3). The greatest differences were found between semi-natural and artificial managed forests. Staphylinid communities of warm oak forests in central Europe are characterized by the presence of rare species with a higher temperature preference (Roubal, 1930; Bohac, 1988a). High species diversity was found in communities of staphylinids in hornbeam-birch (Carpinus-Betula) forests (Table 3). Predators and hygrophilous species living in detritus prevail in communities in these forests. Community index measurements revealed that staphylinid communities in such forests were strongly influenced by man (Bohac, 1988a). The highest species diversity was found in alder (Alnus spp.) forests (Table 3). Many staphylinid species show higher abundance in this type of forest in comparison with other forest ecosystems; some staphylinid species are known exclusively in alder forests. Staphylinid communities in beech forests are less influenced by man in comparison with other semi-natural forests. A higher frequency of species with restricted geographical distribution (west-European and middle European and mountain species) is characteristic for beetle communities of beech forests (Zerche, 1976; Vogel and Dunger, 1980; Schaefer, 1983; Friebe, 1983; Siebart, 1984; Bohac, 1988c). A high frequency of species with restricted distribution is typical for mountain spruce forests in the Carpathians (Roubal, 1930) and Alps (Chemini and Zanetti, 1982). The species diversity, activity and abundance of staphylinids from mountain spruce forests is lower than in other natural ecosystems (Table 3). Artificial forests in the study were represented by pine forests at lower elevations and by spruce forests at higher elevations in central Europe. The species diversity of staphylinid communities in 
plantations forests of spruce is low (Table 3) and depends on the type of soil, vegetation cover and soil moisture (Vogel and Dunger, 1980; Vogel, 1982; Keilbach, 1986). Species with higher temperature preferences and tolerant to dessication prevail in plantation forests of pine. The influence of man on communities of staphylinids in plantation spruce communities is high, especially at lower altitudes. Ubiquitous species are dominant in staphylinid communities of such forests. Some species living in open agricultural landscapes penetrate into these forests. The frequency of saprophagous species in artificial forests is lower in comparison with beetle communities of semi-natural forests. In addition, the species with large body sizes (size Group V) are absent from staphylinid communities in man-made forests.

\subsection{Communities of staphylinids in littoral biotopes and peat bogs}

Staphylinids are mostly hygrophilous or mesophilous and many species are often closely associated with wetlands (Zanetti, 1978; Focarille, 1987; Bohac, 1988a; Frisch, 1995; Bohac et al., 1996). Staphylinid beetles are widely distributed near both running water, such as streams and rivers, and standing waters, such as lakes, marshes, and peat bogs. The structure of communities of staphylinids living near running waters depends on various abiotic and biotic factors (soil type, relief of landscape, plant cover, water pollution, regulation of shores by man, etc.). Comparisons of species diversity and activity of staphylinids from various littoral biotopes (Vogel and Dunger, 1980; Keilbach, 1986; Bohac, 1988a; Bohac and Fuchs, 1994a) indicate great differences in the community structure of various biotopes. The frequency of various ecological groups also varies greatly. Littoral communities generally have high species diversity but the frequency of ubiquitous species in these communities is also often very high (Bohac, 1988a). The species of small and middle body size prevail in communities of littoral biotopes (body size Groups II and III). The main trophic groups are zoophages, with a prevalence of ripicolous geobionts (species living in the shore substrate of streams); temperature and moisture preferences of littoral species are often higher than in other biotopes. Species with a wide distribution are dominant in many communities of littoral biotopes, with the exception of mountain biotopes. Peat bogs have a specific staphylinid fauna. The most characteristic ecological groups in these communities are the tyrphobionts and tyrphophiles, which live exclusively or mainly in peat bogs, respectively (Peus, 1928; Horion, 1962, 1965, 1967; Koch, 1989). Many staphylinid species are closely associated with certain plant communities in peat bogs (Frisch, 1995). Some species occur in portions of peat bogs covered with trees, others in swampy areas or exclusively in raised peat bogs. The species with small body size are dominant in European peat bogs. These areas are characterized by a high proportion of northern Palearctic-boreal and central-European montane species of staphylinid beetles (Frisch, 1995). The frequency of specific ecological groups (paludicolous species, tyrphobionts, tyrphophiles) is generally high (about 50\%) in bogs which have not been harvested for peat. Peat cutting and drainage lead to a change in the bog vegetation and are also reflected in the staphylinid fauna, mainly by the expansion of species from the surrounding wet biotopes and by the absence of tyrphobionts (Alalikina et al., 1980; Bohac et al., 1995; Frisch, 1995).

\subsection{Staphylinid communities in farming areas}

Staphylinids are the second most important group of epigeic invertebrates in agricultural landscapes in terms of activity and abundance (Obrtel, 1968). They represent about $19 \%$ of all beetles in terms of number of individuals. The number of staphylinid species is often higher than that of carabids (Bohac and Pospisil, 1984), and in some biotopes staphylinid abundance can be 15 times greater than that of carabid specimens (Lubke-Al Hussein and Wetzel, 1993). Staphylinids are important predators of some pests e.g., aphids, caterpillars, wire worms and other invertebrates (Scherney, 1955; Fox and Mac Lellan, 1956; Fuldner, 1960; Jones, 1969, 1976; Ienistea and Alex, 1982; Coombes and Sotherton, 1986; Chiverton, 1987; Dennis and Sotherton, 1994). Table 4 lists dominant staphylinid species living in large arable fields. Figs. 8-15 illustrate habitats of selected common species occurring in rural landscapes. In central and western Europe, the staphylinid fauna of fields 
Table 4

Dominant species of staphylinids in various managed ecosystems in studied zones (1: forest steppe, 2: lowland forests)

\begin{tabular}{|c|c|c|c|c|}
\hline Ecosystem & Country & Zone & Source & Dominant species \\
\hline Pasture & Czechia & $\begin{array}{l}1 \\
1\end{array}$ & Bohac, 1988a & $\begin{array}{l}\text { Philonthus cognatus, Tachyporus hypnorum, } \\
\text { Anotylus nitidulus, Platystethus nitens }\end{array}$ \\
\hline Field (maize) & Russia & 2 & Soldatova et al., 1983 & Anotylus insecatus, Atheta fungi \\
\hline Field (wheat) & Russia & 2 & Soboleva-Dokuchaeva and Soldatova, 1983 & $\begin{array}{l}\text { Philonthus rotundicollis, Philonthus laminatus, } \\
\text { Tachyporus hypnorum, Tachinus rufipes }\end{array}$ \\
\hline Field (clover) & Russia & $\begin{array}{l}2 \\
2\end{array}$ & Soboleva-Dokuchaeva and Soldatova, 1983 & $\begin{array}{l}\text { Philonthus rotundicollis, Philotnhus laminatus, } \\
\text { Tachyporus chrysomelinus }\end{array}$ \\
\hline Field (wheat) & Czechia & 2 & Bohac and Pospisil, 1984 & $\begin{array}{l}\text { Dinaraea linearis, Philonthus cognatus, } \\
\text { Tachinus rufies }\end{array}$ \\
\hline Field (maize) & Czechia & 2 & Bohac and Pospisil, 1984 & $\begin{array}{l}\text { Aleochara bipustulata, Oxytelus rugosus, Tachyporus } \\
\text { hypnorum, Philonthus cognatus }\end{array}$ \\
\hline Field (clover) & Czechia & 2 & Bohac, 1988a & $\begin{array}{l}\text { Tachinus signatus, Philonthus cognatus, } \\
\text { Tachyporus hypnorum }\end{array}$ \\
\hline Dispersed belts & Czechia & 2 & Bohac, 1991; Bohac and Pospisil, 1984 & $\begin{array}{l}\text { Sepedophilus pedicularius, Xantholinus linearis, } \\
\text { Tachyporus chrysomelinus, Rugilus rufipes, Atheta fungi }\end{array}$ \\
\hline Ruderals & Czechia & 2 & Bohac, 1986, 1988a & $\begin{array}{l}\text { Anotylus rugous, Philonthus politus, Philonthus succicola, } \\
\text { Philonthus succicola, Aleochara curtula, Falagria caesa }\end{array}$ \\
\hline
\end{tabular}

Table 5

The number of species and abundance (specimens $/ \mathrm{m}^{2}$ ) of staphylinid beetles in various managed ecosystems in studied zones (1: forest steppe, 2: lowland forests)

\begin{tabular}{|c|c|c|c|c|c|}
\hline Ecosystem & Country & Zone & Source & No. of species & No. individuals $/ \mathrm{m}^{2}$ \\
\hline Pasture & Czechia & 2 & Bohac, 1988a & $15-20$ & $8-24$ \\
\hline Field (maize) & Russia & 1 & Utrobina and Tikhomirova, 1968 & 23 & $3-9$ \\
\hline Field (potatoes) & Russia & 1 & Nadvornyi and Petrenko, 1978 & 12 & $2-3$ \\
\hline Field (clover) & Russia & 1 & Nadvornyi and Petrenko, 1978 & 17 & $3-7$ \\
\hline Field (wheat) & Czechia & 2 & Bohac and Pospisil, 1984 & 89 & $14-35$ \\
\hline Field (maize) & $\begin{array}{l}\text { Czechia } \\
\text { Germany }\end{array}$ & 2 & Topp and Trittelwitz, 1980; Bohac and Pospisil, 1984 & $24-54$ & $5-23$ \\
\hline Field (clover) & Czechia & 2 & Bohac, 1988a & 86 & $23-48$ \\
\hline Field (corn) & Italy & 1 & Paoletti, 1988 & 28 & $1.5-7.5$ \\
\hline Dispersed shelter & Italy & 1 & Paoletti, 1988 & 14 & $1.2-2.7$ \\
\hline Dispersed shelter & Czechia & 2 & Bohac, 1991; Bohac and Pospisil, 1984 & 40 & $46-190$ \\
\hline Ruderals & Czechia & 2 & Bohac, 1986, 1988 & 27 & $3-96$ \\
\hline
\end{tabular}

is strongly influenced by the surrounding biotopes (Bohac and Pospisil, 1984; Bohac, 1991; Dennis and Lys, 1992; Hulster and Desender, 1984). Generally, the number of staphylinid species in fields increases from one-year cultures to cultures growing for several consecutive years (Table 5). The species diversity and abundance of beetles in fields increase from north (zone of taiga) to south (zone of lowland forests and forest steppe) (Bohac, 1988a).

\subsubsection{Staphylinids as bioindicators of management in fields}

Agricultural measures (tillage, manure, chemical NPK and pesticides) have a lower and more short-term influence on staphylinid communities compared with other factors such as relief of agricultural landscape, surrounding biotopes, soil humidity and crop change (Bohac, 1991). Nevertheless, staphylinid beetles are good indicators of changes in agricultural techniques (Table 6).

3.3.1.1. The influence of crop change on staphylinids. The change of crop from wheat to maize was shown to influence the dominance of staphylinid species in communities (Bohac and Pospisil, 1984). Some species with good migratory ability colonized the maize field but were not found in the wheat field; these species were subdominant in the maize field (e.g., Philonthus 
Table 6

The influence of some types of management on staphylinids in agricultural landscapes

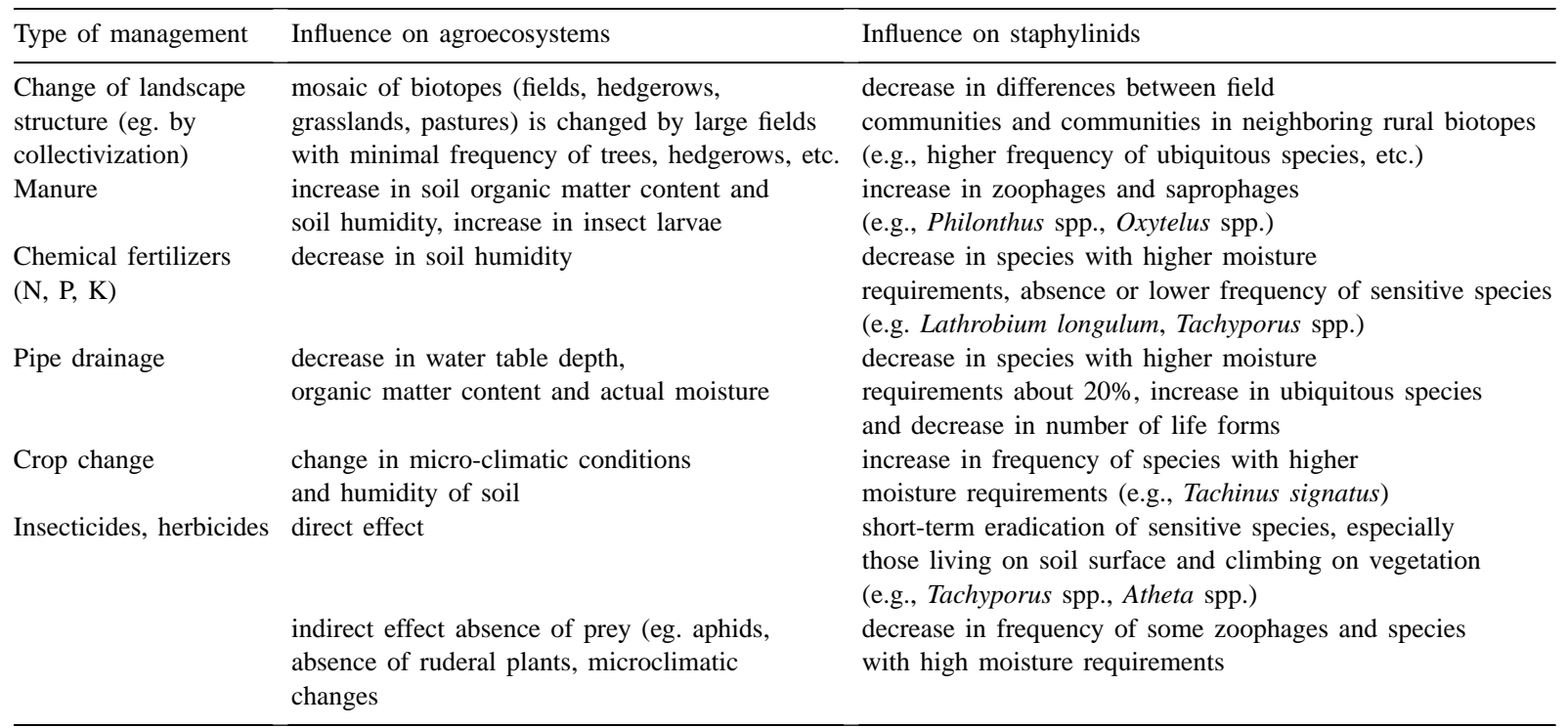

rectangulus). The higher humidity of the soil in the maize field facilitated its colonization by hygrophilous staphylinid species (e.g., Othius punctulatus, Philonthus decorus) from the surrounding biotopes.

\subsubsection{The influence of tillage on staphylinids}

Observations made to date do not indicate a negative influence of tillage on staphylinid beetles living in fields (Konig and Pawlitzki, 1981; Bohac, 1988a); the species number and abundance of beetles can even increase with tillage (28 species and 270 specimens $/ \mathrm{m}^{2}$ on a plot immediately after tillage and 23 species and 240 specimens $/ \mathrm{m}^{2}$ on a control plot without tillage) (Bohac, 1988a). On the other hand, shortly after tillage the activity of staphylinid imagos and larvae was found to decrease by approximately 20 -fold in comparison with their activity before tillage (Bohac, 1988a). This may be explained by the limited ability of imagos from the surrounding biotopes to colonize the disturbed surface soil of fields after tillage (Bohac and Pospisil, 1984).

\subsubsection{The influence of manure and NPK fertilizers on staphylinids}

The effect of various NPK doses ( $30 \mathrm{q}$ NPK/ha, $60 \mathrm{q}$ $\mathrm{NPK} / \mathrm{ha}$ ) and farmyard manure on soil macrofauna was studied in fields planted with barley (Bohac and
Pokarzhevski, 1987). Staphylinid abundance was stimulated by manure; this effect was also observed for other predators (Carabidae, Chilopoda) and reflected an increase in the quantity of their prey. The manure also raised the soil moisture content and therefore produced an increase in the number of hygrophilous species. The lowest number of staphylinid species was found on the plot with the highest dose of NPK. Some staphylinid species were good indicators of the type and dose of fertilizers. Species of the genus Tachyporus had the highest density on the control plot without fertilizers and the density of beetles increased from the plot with a lower dose of NPK to the plot with organic manure. The staphylinid species Lathrobium longulum was found only on plots without fertilizers.

\subsubsection{The influence of pesticides on staphylinids}

The effect of insecticides on staphylinids has been studied both in the laboratory and in field experiments. Various insecticides were tested in the laboratory on two common field staphylinid species, Philonthus cognatus and Tachyporus hypnorum. The abundance of both species decreased by 40-50\% after the treatment (Eghtar, 1969); the larvae of both species were more sensitive than imagos. No increase in beetle sterility was noted after treatment with insecticides. On the other hand, pyrethroids had a negative influence 
on oviposition by Aleochara species under laboratory conditions (Samsoe-Petersen, 1985). Exposure to methoxychlor decreased the activity and abundance of staphylinids in fields (Topp, 1978; Konig, 1983); their activity and abundance were restored to the same level as before treatment after approximately one month. The effect of insecticides on staphylinid communities depended on the vegetation cover and presence of litter (Sustek, 1982). The insecticide influenced staphylinid beetles living in forested landscapes to a lesser extent compared with non-forested landscapes because of the accumulation of insecticide on vegetation and its faster degradation in litter. In contrast, herbicide treatment did not appear to influence activity of staphylinid beetles in a field experiment (Bohac and Pospisil, 1984).

\section{Staphylinids as bioindicators of land use in agricultural settlements}

Staphylinid communities are strongly influenced by the structure of cultural landscapes (Bohac and Pospisil, 1984; Bohac and Fuchs, 1994a, 1994b; Bohac et al., 1995). The effects of land use on staphylinid communities of six villages in two rural areas in south and north Bohemia with different intensities of management were analyzed using pitfall trapping (Bohac and Fuchs, 1994a, 1994b). The entire villages, separate sites within them and surrounding fields were compared. The effect of more intensive land use was distinct: species composition in south Bohemian villages with more intensive management was richer than in north Bohemian settlements, possibly the reason of the higher number of habitats and sharper boundaries among them. The number of beetle species in particular villages did not depend on the size of the settlement. In both regions, the beetle communities of medium and large-sized villages were more similar than in small villages. A dissimilarity was not found between beetle communities in particular sites in villages and in the surrounding fields. The results were practically the same for both staphylinids and carabids.

\section{Long-term monitoring of staphylinid com- munities in montane ecosystems influenced by man}

The effect of air pollution and forest decline on epigeic staphylinid communities was studied in the Giant Mountains (north-east Bohemia) (Bohac, 1992; Bohac and Fuchs, 1995). Comparison of staphylinid communities during the years 1983-1984 and 1988-1989 indicated early stages of changes in three out of five ecosystems studied. These ecosystems (damaged spruce forest, peat bog and stony slope) were more diverse during 1988-1989 than during 1983-1984. The greatest changes were found in the damaged spruce forest, where the frequency of ubiquitous and more tolerant species living in open landscapes increased, whereas that of stress-sensitive forest-living species decreased. Some species living beneath the bark of dying trees and in wet open biotopes appeared. There were no distinct changes in ecosystems regularly disturbed by natural factors such as avalanches and water erosion (glacial cirque, mountain floodplain meadow). Staphylinid communities were studied during the years 1986-1996 in mountain forest under the influence of industrial emissions in the Kruçn, mountains, located in the north-western region of the Czech Republic (Kula and Bohac, 1996). The dominance of some species varied significantly in various years. Two groups of species were identified by their changes in abundance from year to year: those species showing important changes in abundance and activity and those species with approximately the same abundance and activity from year to year. The frequency of ubiquitous species was found to have increased in all types of forest at the end of the ten-year monitoring period.

\section{Staphylinids in urbanized areas}

Urban areas are modified and fragmented by human activity. The spectrum of biotopes in urban areas varies from semi-natural (urban parks, small forests, hedgerows, etc.) to biotopes strongly influenced by man (ruderal situations, spoil banks, human settlements, etc.). The staphylinid fauna of urban areas may be partitioned into ubiquitous and eurytopic species, and habitat specialists. The author carried out a comparison of staphylinid communities living in urban parks and ruderal biotopes within and surrounding Prague (Bohac, 1989a). Beetle communities in Prague parks were found to be very similar to those of semi-natural forests in the vicinity of the city. The ecological structure of beetle communities 
in studied parks differs depending on management, with parks under weaker management having beetle communities more similar to those of semi-natural forests. The character of staphylinid communities in ruderal habitats is typical for unmatured biotopes. Many species of staphylinid beetles that were found in parks, were not found in semi-natural forests in the vicinity of the city. These were mainly species living in cavities of trees, which can often be found in parks, but are usually removed from managed forests. Parks also contain many other special habitats advantageous for the survival of staphylinids, e.g., nests of small mammals, mushrooms, etc. The species living in ruderal biotopes are often found on various decaying matter, waste or leftovers (Bohac, 1989a). Predators and parasites are the dominant trophic groups here; some species are saprophagous and some may be synanthropic. The large and well sclerotized species that resist drying and possess higher thermopreference prevail in these biotopes. Eurytopic staphylinid species typical for ruderal habitats were found to be dominant in urban parks studied by several authors (Topp, 1972; Klausnitzer et al., 1982; Kroker and Renner, 1983). These observations can be explained by the fact that pitfall trapping was used for collecting staphylinids, a method that selects for the more active and heavies species.

\section{Accumulation of metals in staphylinids and their role as bioindicators of radionuclides}

With respect to accumulation of heavy metals, invertebrates in terrestrial ecosystems can be divided into three classes, i.e., macroconcentrators, microconcentrators and deconcentrators (Bohac and Pospisil, 1988). For this classification the biological accumulation coefficient $k$ is used, which is defined as the ratio of the metal concentration in the animal body to its concentration in soil. Species with $k 2$ are classed as macroconcentrators, species, with $1 k 2$ are classed as microconcentrators and species, while $k 1$ are classed as deconcentrators. Although this classification is actually affected by the concentrations of elements in the environment, it is very convenient for evaluation of an insect's ability to accumulate toxic substances in different ecosystems with the same level of pollution. Staphylinids are mainly microconcentrators of heavy metals (Bohac, 1989b), but some are known to be macroconcentrators. Macroconcentrators can be particularly suitable biomonitoring objects. These macroconcentrators mainly belong to certain trophic groups, and the concentration of chemical elements in bodies of staphylinids depends on their trophic patterns. Elevated concentrations of lead were observed in some zoophagous species and elevated concentrations of mercury in some mycetophagous species (Bohac et al., 1989). The elevated mercury levels in mycetophages reflects the fact that some fungi are capable of accumulating this element. Staphylinids are not as sensitive to pollution by radionuclides as some other groups of soil fauna (Krivolutsky and Pokarzhevsky, 1992). The larvae are more sensitive than imagos.

\section{Conclusions - perspectives for use of staphylinids as bioindicators}

Many species of the family Staphylinidae show good bioindicating features thanks to their ecological specialization. In general, staphylinids are a good source of valuable complementary knowledge in bioindicative studies. In some cases staphylinids are more suitable and sensitive bioindicators than carabid beetles, but their importance for biomonitoring is currently limited because of difficulties in their identification. Furthermore, many species are not easily found using quantitative sampling methods (pitfall trap, soil samples). The fact that some staphylinids, carabids and spiders compete for food sources probably influences the results of bioindicative studies, therefore necessitating more complex bioindicative studies with all types of insects. Future refinements in identification and sampling methods and additional information regarding the interaction of staphylinids with other insects and their environment should result in their increased use as bioindicators of environmental quality.

\section{Acknowledgements}

The author thanks Mgr. Matus Kocian (Prague) for redrawing of figures and Ing. Frantisek Novak (Ceske Budejovice) for help with graphic preparation of the figure illustrating the influence of man on beetle communities. 


\section{References}

Alalikina, N., Artemyeva, T., Borisovich, T., Bursakov, S., Vertogradskaya, I., Garkusha, T., Zherebtsov, A., Zverkov, Y., Krilova, L., Nekrasova, K., Sevastyanov, V., Sidorova,. L., 1980. Soil Fauna and Biological Activity on Drained Peat Bogs. Nauka, Moscow, 170 pp. (in Russian).

Blackwelder, R.E., 1936. Morphology of the coleopterous family Staphylinidae. Smithson. Misc. Collect. 94, 102.

Bohac, J., 1982. The larval characters of Czechoslovak species of the genera Abemus, Staphylinus and Ocypus. Studie CSAV, 4, Academia, Praha, 96 pp.

Bohac, J., Pospisil, J., 1984. Carabids and staphylinids of wheat and maize fields and their relationships with surrounding biotopes. Sov. Rev. Ecol. 3, 22-34.

Bohac, J., Gusev, A.A., Guseva, N.A., Pokarzhevskii, A.D., 1984. Staphylinid beetles in soils of the Central Chernozem Reserve. In: Ecological and Faunistical Investigations in the Central Forest Steppe of the European Part of the USSR. Lesnaya Promyshlenost, Moscow, pp. 91-104. (in Russian).

Bohac, J., 1986. Kurzfluglerkafer als Bioindikatoren fur okologische Gleichgewichte einer Landschaft und menschlichen Einfluss. In: Paukert, J., Ruzicka, V., Bohac, J. (Eds.), Proc. 4th Int. Conf. Bioindicatores Deteriorisationis Regionis, Institute of Landscape Ecology CAS, Ceske Budejovice, pp. 23-34.

Bohac, J., Pokarzhevski, A., 1987. The effect of various doses of manure and NPK on soil fauna in chernozem soil. In: Szegi, J. (Ed.), Proc. 9th Int. Symp. on Soil Biology and Conservation of Biosphere. Akad. Kiado, Budapest, p. 25-27.

Bohac, J., 1988a. Staphylinid beetles - bioindicators of anthropogenous changes of the environment. Thesis, University of Ceske Budejovice (in Russian).

Bohac, J., 1988b. Communities of staphylinid beetles (Coleoptera, Staphylinidae) as bioindicators of the quality of the environment. Zpravy Cs. Spol. Ent., Praha 24, 33-41 (in Czech with English summary).

Bohac, J., 1988c. Staphylinidae of various biotopes of the Tyrov state reserve in central Bohemia. Bohemia Centralis 1, 145-155.

Bohac, J., Pospisil, J., 1988. Accumulation of heavy metals in invertebrates and its ecological spects. Abstracts of the Int. Conf. Heavy Metals in the Environment. CEP Consultants Publishers, Norwich, vol. 2, pp. 354-357.

Bohac, J., Ruzicka, V., 1988. The use of communities of epigeic invertebrates (Araneae, Coleoptera, Carabidae, Staphylinidae) for bioindication of the environmental quality. Sov. J. Ecol. 19, 56-63.

Bohac, J., Krivolutski, D., Antonova, T., 1989. The role of fungi in the biogenous migration of elements and in the accumulation of radionuclides. Agric. Ecosyst. Environ. 28, 31-34.

Bohac, J., 1989a. Fauna of staphylinid beetles (Coleoptera, Staphylinidae) of two Prague parks and its comparison with other biotopes. Verhandlungen IX. SIEEC, Dresden, pp. 130-133.

Bohac, J., 1989a. Accumulation of heavy metals in the bodies of staphylinid beetles (Coleoptera, Staphylinidae). In: Bohac, J., Ruzicka, V. (Eds.), Proc. Vth Int. Conf. Bioindicatores Deteriorisationis Regionis. Institute of Landscape Ecology CAS, Ceske Budejovice, pp. 319-321.
Bohac, J., 1990. Numerical estimation of the impact of terrestrial ecosystem by using the staphylinid beetles communities. Agrochem. Soil Sci. 39, 565-568.

Bohac, J., Ruzicka, V., 1990. Size groups of staphylinid beetles (Coleoptera, Staphylinidae). Acta Entomol. Bohemoslov. 87, 342-348.

Bohac, J., 1991. The effect of dispersed belts in agroecosystems on communities of epigeic beetles. In: Mahn, E.G., Tietze, F. (Eds.), Agro-Okosysteme und Habitatinseln in der Agrarlandschaft. Universitat Halle-Wittenberg, p. 289-294.

Bohac, J., Fuchs, R., 1991. The structure of animal communities as bioindicators of landscape deteriorisation. In: Jeffrey, D.W., Madden, B. (Eds.), Bioindicators and Environmental Management. Academic Press, London, pp. 165-178.

Bohac, J., 1992. Effect of atmospheric pollution and forest decline on beetle communities. In: Bohac, J. (Ed.), Proc. VIth Int. Conf., Bioindicatores Deteriorisationis Regionis, Institute of Landscape Ecology CAS, Cesk, Budejovice, p. 159-165.

Bohac, J., 1994. Faunistical and ecological investigation of staphylinid beetles in National Natural Reserve 'Brouskuv mlyn' in Southern Bohemia. Agency of Nature Conservation, Division Ceske Budejovice, 28 pp.

Bohac, J., Fuchs, R., 1994a. Carabidae and Staphylinidae of Bohemian villages. In: Desender, K., Dufrene, M., Loreau, M., Luff, M.L., Maelfait, J.-P. (Eds.), Carabid Beetles: Ecology and Evolution. Kluwer Academic Publishers, Dordrecht, pp. 235-240.

Bohac, J. and Fuchs, R., 1994b. Classification and ordination of habitats of staphylinid beetles (Coleoptera, Stahylinidae) in agricultural landscape of central and east Europe. Abstracts of 5th European Congress of Entomology, University of York, York, p. 30.

Bohac, J., Fuchs, R., 1995. The effect of air pollution and forest decline on epigeic staphylinid communities in the Giant Mountains. Acta Zool.Fennica 196, 311-313.

Bohac, J., Kubes, J., Fuchs, R., Curnova, A., 1995. The use of biomonitoring for ecological planning and ecological policy in agricultural settlements. In: Munawar, M., Hanninen, O., Roy, S., Munawar, N., Karelampi, L; Brown, D. (Eds.), Bioindicators of Environmental Health. SPB Academic Publishing, Amsterdam, pp. 155-163.

Bohac, J., Karas, V., Fuchs, R., 1996. The long-term investigations of beetles (Coleoptera, Staphylinidae) in Trebon Biosphere reserve. Verhandlungen des 14. Internationalen Symposiums fur Entomofaunistik in Mitteleuropa, SIEEC, Munchen 1994, SIEEC, Munchen, p. 427.

Bohac, J., Syrovatka, O., Frouz, J., 1995. Communities of carabids and staphylinids in restored wetlands in southern Bohemia. Abstracts of 3rd Int. Symp. Carabidology, University of Helsinki, Helsinki, p. 39.

Chemini, C., Zanetti, A., 1982. Censimenti di Coleotteri Stafilinidi in tre ambientali forestali di Magre e favogna (Provincia Bolzano). Studi Trentini di Sci. Natur. Acta Biologica 59, $213-$ 220.

Chiverton, P.A., 1987. Predation of Rhopalosiphum padi (Homoptera, Aphididae) by polyphagous predatory arthropods during the aphis pre-peak period in spring barley. Ann. Appl. Biol. 111, 257-269. 
Coiffait, H., 1972. Coleopteres Staphylinidae de la Region Palearctique Occidentale. I. Generalites, Sous-familles: Xantholininae et Leptotyphlinae. Nouv. Rev. Entomol. Suppl. 2 (2), $651 \mathrm{pp}$.

Coombes, D.S., Sotherton, N.W., 1986. The dispersal and distribution of polyphagous predatory Coleoptera in cereals. Ann. Appl. Biol. 108, 461-474.

Crowson, R.A., 1981: The Biology of Coleoptera. Academic Press, London, $802 \mathrm{pp}$.

Dennis, P., Lys, G.L.A., 1992. Field margins: can they enhance natural enemy population densities and general arthropod diveristy on farmland?. Agric. Ecosyst. Environ. 40, 25-31.

Dennis, P., Sotherton, N.W., 1994. Behavioral aspects of staphylinid beetles that limit their aphid feeding potential in cereal crops. Pedobiologia 38, 222-237.

Eghtar, E., 1969. Die Empfindlichkeit von Philonthus fuscipennis Mannh. und Tachyporus hypnorum L. (Coleoptera, Staphylininidae) gegenuber Insektiziden. Nachrichtenbl. Dtsch. Pflanzenschutzdienst 21, 182-185.

Evans, M.E.G., 1964. A comparative account of the feeding methods of beetles Nebria brevicollis (F.) (Carabidae) and Philonthus decorus (Grav.) (Staphylinidae). Trans. R. Soc. Edinburgh 66, 91-109.

Focarille, A, 1987. Ecologie et biogeographie des Coleopteres de haute altitude en vallee d Aoste. Assess. Agric. Foreste e Ambiente naturale, serv. Selviolt. (Aoste), 90 pp.

Fox, C.J.C., Mac Lellan, C.R., 1956. Some Carabidae and Staphylinidae shown to feed on a wireworm Agriotes sputator by precipitative test. Can. Ent. 88, 228-231.

Frank, J.H., 1982. The parasites of the Staphylinidae (Coleoptera). A contribution towards an encyclopedia of the Staphylinidae. Univ. Florida Agr. Exp. Stns, Tech. Bull. 824, i-vii, 1-118.

Frank, J. H., 1991. Staphylinidae. In: Stehr F.W. (Ed.), An Introduction to Immature Insects of North America. Kendall-Hunt, Dubuque, Iowa, vol. 2, pp. 341-352.

Friebe, B., 1983. Zur Biologie eines Buchenwaldbodens. 3. Die Kaferfauna. Carolinea 41, 45-80.

Frisch, J., 1995. Die Kaferfauna des roten moores (Insecta: Coleoptera). Eine okologisch-faunistische Studie zur Kaferfauna der Rhonmoore. Beitrage zur Naturkunden in Osthessen 30, 3-180.

Fuldner, D., 1960. Beitrage zur Morphologie und Biologie von Aleochara bilineata Gyll. und A. bipustulata L. (Coleoptera, Staphylinidae). Z. Morphol. Okol. Tiere 49., 312-386.

Hinton, H.E., 1981. Biology of insect eggs. Pergamon Press. London, NY, vol. 1. 1-3, $1125 \mathrm{pp}$.

Horion, A., 1962. Faunistik der deutschen Kafer, Bd. 9. Staphylinidae 1. Teil (Micropeplinae-Euasthetinae). A. Feyel, Uberlingen-Bodensee, 408 pp.

Horion, A., 1965. Faunistik der deutschen Kafer, Bd. 10. Staphylinidae 2. Teil (Paederinae-Staphylininae). A. Feyel, Uberlingen-Bodensee, 355 pp.

Horion, A.,1967. Faunistik der deutschen Kafer Bd. 11 taphylinidae 3.Teil (Habrocerinae-Aleocharinae. A. Feyel, Uberlingen-Bodensee, 419 pp.

Hulster, M.D., Desender, K., 1984. Ecological and faunal studies of Coleoptera in agricultural land. IV. Hibernation of Staphylinidae in agroecosystem. Pedobiologia 26, 65-73.
Ienistea, M., Alex, F.K., 1982. Die Aleochara (Coleoptera, Staphylinidae) Rumaniens unter besonderer Berucksichtigung der an Fliegenpuparien gezuchteten Arten. Ent. B1. 78, 20-30.

Jones, M.G., 1969. The effects of weather on frit fly (Oscinella frit L.) and its predators. J. Appl. Ecol. 6, 425-441.

Jones, M.G., 1976. The arthropod fauna of a winter wheat field. J. Appl. Ecol. 13, 61-85.

Keilbach, R., 1986. Ergebnisse aus Fallenfangen von Staphylinidae im Forst von Kuhlenhagen bei Wolgast (NO der DDR) (Coleoptera, Staphylinidae). Dtsch. ent. Z., N.F. 33, 277-281.

Kistner, D.H., 1979. Social and evolutionary significance of social insect symbionts. In: Herman, H.R. (Ed.), Social Insects. Academic Press, New York, pp. 340-413.

Klausnitzer, B., Koberlein, C., Koberlein, F., Vogel, J., Uhlig, M., 1982. Zur Staphylinidenfauna zweier leipziger Stadtparks (Insecta, Coleoptera). Faun. Abh. Mus. Tierk. Dresden 9, 195202.

Koch, K., 1989. Die Kafer Mitteleuropas, Okologie E1. Goecke and Evers, Krefeld, 440 pp.

Konig, K., 1983. Untersuchungen uber die Auswirkungen der Anwendung von Insektiziden auf die epigaische fauna von Zuckerrubenflachen. Bayer. Landwirtschftl. Jahrbuch 60, 235312.

Konig, K., Pawlitzki, K.H., 1981. Untersuchungen uber Auswirkungen unterschiedlichen Bewirtschaftunintensitat auf die epigeische fauna von Zuckerrubenflachen. Bayer. Landwirtschftl. Jahrbuch 58, 285-290.

Krivoluckij, D.A., Bohac, J., 1989. Life forms and morphogenesis of animals: the use in bioindication of the environment quality (on example of staphylinid beetles). In: Bohac, J., Ruzicka, V. (Eds.), Proc. Vth Int. Conf. Bioindicatores Deteriorisationis Regionis. Institute of Landscape Ecology CAS, Ceske Budejovice, pp. 141-146.

Krivolutsky, D.A., Pokarzhevsky, A.D., 1992: After effect of radioactive fallouts on soil populations in the $30 \mathrm{~km}$ area of the Chernobyl atomic power station accident. In: Bohac, J (Ed.), Proc. VIth Int. Conf. Bioindicatores Deteriorisationis Regionis. Institute of Landscape Ecology CAS, Ceske Budejovice, pp. 486-495.

Kroker, H., Renner, K., 1983. Beitrag zur Kenntnis der Staphylinidenfauna unbewaldeter Habitate der Warburger Borde. Bayer. Landw. Jahrbuch 1081, 285-290.

Kula, E., Bohac, J., 1996. Communities of staphylinid beetles in spare forest ecosystems under the influence of anthropogenic factors. Scientific Report, Ministry of Agriculture, Brno, $42 \mathrm{pp}$.

Lohse, G.A., 1964. Staphylinidae I. (Micropeplinae bis Tachyporinae) In: Freude, H., Harde, W., Lohse, G.A. (Eds.), Die Kafer Mitteleuropas. Goecke and Evers, Krefeld, 364 pp.

Lohse, G.A., Benick, G., Likovsky, Z., 1974. Staphylinidae II (Hypocyphtinae bis Aleocharinae). In: Freude, H., Harde, W., Lohse, G.A. (Eds.), Die Kafer Mitteleuropas. Goecke and Evers, Krefeld, 304 pp.

Lubke-Al Hussein, M., Wetzel, T., 1993. Aktivitatsund Siedlungsdichte von epigaischen Raubarthropoden in Winterweizenfeldern im Raum Halle/Saale. Beitr. Ento. 43, 129-140. 
Nadvornyi, V.G., Petrenko, A.A., 1978. Staphylinid beetles of the valley of the Dnepr River. In: Problems of Soil Zoology, Science and Techniques, Minsk, pp. 164-166 (in Russian).

Naomi, S.I., 1987. Comparative morphology of the Staphylinidae and the allied groups (Coleoptera, Staphylinoidea) I. Introduction, head sutures, eyes and ocelli. Kontyu (Tokyo) 55, $450-458$.

Newton, A.F., Jr., 1984. Mycophagy in Staphylinoidea (Coleoptera). In: Wheeler, O., Blackwell, M. (Eds.), Fungus-Insecta Relationships. Columbia University Press, New York, pp. 302-351.

Newton, A. F., Jr., 1990. Insecta: Coleoptera, Staphylinidae, adults and larvae. In: Dindall, D.L. (Ed.), Soil Biology Guide. Wiley, New York, pp. 1137-1174.

Obrtel, R., 1968. Carabidae and Staphylinidae occurring on soil surface in luzerne fields (Coleoptera). Acta Entomol. Bohemoslov. 65, 5-20.

Paoletti, M.G., 1988. Soil invertebrates in cultivated and uncultivated soils in northern Italy. Redia 71, 501-563.

Paulian, R., 1941. Les premiers etats des Staphylinoidea. Etude de morphologie comparee. Mem. Mus. Nat. Paris, vol. 15, 361 pp.

Peus, F., 1928. Zur Charakteristik der Tierwelt nordwestdeutscher Hochmoore. Sitz. Ber. Ges., 102, Berlin.

Pototskaya, V.A., 1967. Key for identification of rove beetles (Coleoptera, Staphylinidae) of the european part of the USSR. Nauka, Moscow, 119 pp. (in Russian).

Razumovskii, S.M., Tikhomirova, A.L., Bohac, J., Karaseva, N.A., 1984. Dynamics of ecosystems in Kostroma research station. In: Sokolov, V.E. (Ed.), Ecology of Southern Taiga. Nauka, Moscow, pp. 91-122 (in Russian).

Roubal, J., 1930. Coleoptera in soil of Carpathian mixed forest. Vøts. Spol. Zool. 8, 97-130 (in Czech with German summary).

Ruzicka, V., 1985. The size groups in the spiders (Araneae) and carabids (Col., Carabidae). Acta Univ. Carol., Biol 1982-1984, 77-107.

Ruzicka, V., Bohac, J., 1994. The utilization of epigeic invertebrate communities as bioindicators of terrestrial environmental quality. In: Salanki, J., Jeffrey, D., Hughes, G.M. (Eds.), Biological Monitoring of the Environment: A Manual of Methods, CAB International, Wallingford, pp.79-86.

Rybalov, L.B., Tikhomirova, A.L., 1994. The use of beetles (Coleoptera) for biodiagnostics of soil condition in the Moscow egion. In: Particulars of the Soil Animal Population of Moscow Region. Nauka, Moscow, pp. 44-73 (in Russian).

Samsoe-Petersen, L., 1985. Laboratory tests to investigate the effects of pesticides on two beneficial arthropods: a predatory mite (Phytoseiulus persimilis) and a rove beetle (Aleochara bilineata). Pestic. Sci. 16, 321-331.

Schaefer, M., 1983. Kurzflugler (Coleoptera: Staphylinidae) als Teil des Okosystems 'Kalkbuchenwald'. Verh. Gesell. Okol. (Festschrift Ellenberg) 11, 261-372.

Scherney, F., 1955. Untersuchungen uber Vorkommen und Wirtschaftliche Bedeutung rauberisch lebenden Kafer in Feldkulturen. Z. Pflanzenbau Pflanzenschutz 6, 49-73.

Sharova, I., CH., 1981. Life Forms of Carabids (Coleoptera, Carabidae). Nauka, Moscow, 359 pp. (in Russian).

Siebart, H., 1984. Die Kafer (Coleoptera) in Buchenwald bei Braunschweig. Braunsch. Naturk. Schr. 2, 131-143.
Smetana A., 1958. Drabcici - Staphylinidae I, Staphylininae. Fauna CSR, Praha, NCSAV, 437 pp. (in Czech with German summary).

Soboleva-Dokuchaeva, I. I., Soldatova T.A., 1983. The influence of ecological conditions in agroecosystems on soil predator beetles (Carabidae, Staphylinidae). In: Fauna and Ecology of Soil Invertebrates of Moscow Region. Nauka, Moscow, pp. 120-130 (in Russian).

Soldatova, T.A., Soboleva-Dokuchaeva, I. I., Chernova L. B., 1983: The distribution of soil predator beetles (Carabidae, Staphylinidae) in maize field. In: Fauna and Ecology of Soil Invertebrates of Moscow Region. Nauka, Moscow, pp. 130-136 (in Russian).

Spicarova, N., 1982. Discussion to periodicity in the diurnal activity of rove beetles (Coleoptera, Staphylinidae). Acta Univ. Palack. Olom., Fac. re. natur. biol. 22, 105-120.

Sustek, Z., 1982. The effect of actellic EC 50 on the Carabidae and Staphylinidae in a Norway spruce forest in the Jizerske hory mountains. Biologia (Bratislava) 37, 131-139.

Szujecki, A., 1966. First larval stage of Staphylinus dimidiaticornis Gemm. and Staphylinus erythropterus L. (Coleoptera, Staphylinidae). Bull. Acad. Polon. Sci. Ser. Biol. 5, 233-239.

Tikhomirova, A.L., 1973. Morpho-ecological characteristics and phylogeny of staphylid beetles (with catalogue of USSR). Nauka, Moscow, 190 pp.(in Russian).

Tikhomirova, A.L., 1982. Fauna and ecology of staphylinid beetles (Coleoptera, Staphylinidae) in the Moscow vicinity. In: Soil Invertebrates of Moscow region. Nauka, Moscow, pp. 201-222. (in Russian).

Topp, W., 1972. Die Besiedlung eines Stadtparks durch Kafer. Pedobiologia 12, 336-346.

Topp, W., 1978. Bestimmungstabelle fur Larven der Staphylinidae. In: Klausnitzer, B. (Ed.), Ordnung Coleoptera (Larven). Akademia Verl., Berlin, pp. 304-334.

Topp, W., Trittelwitz, W., 1980. Verteilung und Ausbreitung der epigeischer Arthropoden in der Agrarlandschaft II. Staphylinoidea. Anz. Schadlingskde. Pflanzunschutz Umweltschutz 53, 33-36.

Utrobina, I.M., Tikhomirova, A.L., 1968. Staphylinids of fields of the central stream of the Volga river. In: Materials on Ecology of Soil Invertebrates. Kazan University, Kazan, pp. 116-140 (in Russian).

Vogel, J., 1982. Okologische Untersuchungen auf der Staphyliniden-Fauna (Coleoptera, Staphylinidae) des Hakelwaldes im Bezirk Halle (DDR). Hercynia N. F. 19, 146170.

Vogel, J., Dunger, W., 1980. Untersuchungen uber Struktur und Herkunft der Staphyliniden-Fauna (Coleoptera, Staphylinidae) einer Rasen-Wald-Catena in Thuringen (Leutretal bei Jena). Abh. Ber. Naturkundemuseums Gorlitz 53, 1-46.

Wilson, E.O., 1971. The Insect Societies. Harvard University Press, Cambridge, MA 583 pp.

Zanetti, A., 1978. Ricerche sugli Stafilinidi della Media Anaunia (Coleoptera). Studi Trentini Sci. Nat. (Acta Biol.) 55, 77-90.

Zerche, L., 1976. Wechselburg-ein neuer Fundort seltener Kafer im Bezirk Karl-Marx. Stadt. Ent. Nachr. 20, 53-80. 